\title{
The Role of Sources in Historical Memory: Evacuee Children of Second World War Britain
}

\section{Sarah Oeste}

After experiencing the horror of the first nights of the 1940-1941 air raids on Britain in

the Second World War, four children stood solemnly on a London train station platform, ready to depart. They wove their way through the sea of forlorn parents and joined the other children on the nearly-full train. As they made their final farewells to their waving mother through a small window, the train departed, whisked them off to the English countryside and eventually deposited them in what seemed like the middle of nowhere. There, they would stay on a country estate, discover their newfound freedom to play and explore, and eventually they would go on amazing adventures in a magical land that they found in the back of a wardrobe. Such was the evacuation experience of Peter, Susan, Edmund, and Lucy Pevensie in the cinematic retelling of C. S. Lewis's The Chronicles of Narnia: The Lion, the Witch, and the Wardrobe. For many children, myself included, this movie was a first introduction to the child evacuees of Second World War England. Shortly after watching this movie, I watched Disney's Peter Pan: Return to Neverland, which also opened with a bombed London and Wendy Darling receiving the news that her children, Jane and Danny, are to be evacuated in the morning. Jane does not take the news well, but is soon kidnapped away to Neverland. By the end of the film, Jane comes to fully embrace the charge of watching over her younger brother as they are moved out of the city. I thought that evacuation must be a big adventure if it were to narratively follow with a visit with Peter Pan or Aslan. In both cases, these movies portray the evacuation experience as something initially sad, but that ultimately provides happiness and satisfaction. 
There are two main ideas that these movies provide. Firstly, each person today will view the evacuation experience in a different light. For those like my younger self, the evacuations were a positive thing. Who would not want to live in a big mansion and have adventures? The evacuations saved lives and gave the evacuees a unique opportunity to experience life in the countryside. However, other people today might have a different view of the evacuations. When discussing the evacuations with a co-worker, she commented that the evacuations must have been very tragic. She could not imagine being separated from her children and sending them off into the unknown. For a mother like her, the evacuations would have been a source of sadness and indecision.

The second way that these movies are relevant to the discussion of the evacuations is in contemplating which sources people use to formulate their own views and memories of the historical event. Current media often places the evacuations within a narrative, as a starting point for a nearly completely unrelated story. Although historians do not use these as valid sources, the general population unintentionally would if they were not exposed to different perspectives on the same topic. There are other sources too, each with their own unique perception and portrayal of the evacuations: artifacts, memoirs, academic books, and more. Each of these sources have strengths and limitations, but despite any shortcomings, they help shape the contemporary memory of whether or not the evacuations were a success.

In this paper, I will focus on three different types of sources: primary source artifacts such as pictures and video, memoirs from the voices of the evacuees themselves, and academic secondary sources. Each of these sources reveals a different opinion on how good or bad the evacuation program was at the time. They also have both short-comings and advantages which historians must consider when they use them as sources in their research on the historical period. 
Lastly, these sources influence and are influenced by the collective memory of the child evacuations during the Second World War.

Focusing specifically on the debate regarding whether or not the evacuations were a success or failure provides a platform on which these sources can present different views of the same historical event. It shows the importance of understanding the credentials and influence of

these sources, as each source changes how historians and the public remember the evacuations. If researchers remain critical of the sources they use, when combined, these primary and secondary sources create a more complete view of history. Researching child evacuees is an interesting topic in and of itself, and understanding the influences and credentials of the sources historians can use in this debate help explain how people have come to remember the evacuations as either a success or as a failure.

\section{Background Knowledge}

The planning for the evacuation of children, expectant mothers, the mentally disabled, and others began well before the outbreak of the Second World War, but was still highly theoretical in its approach until 1938. The organizers divided Britain into three different regions that would change over the course of the war depending on their likelihood of being targeted by German raids. Evacuation areas were major cities (such as London or Plymouth), industrialized sectors, and military bases that were obvious targets. Evacuees from these areas of Britain would go to various Reception areas in the countryside, which were deemed safe and low risk targets of German raids. In the middle of these two groups were the neutral zones, which were not encouraged to evacuate or receive evacuees themselves. There were three waves of evacuations during the Second World War. The September 1939 evacuations took place as Britain prepared for war and, although good practice, were ultimately unnecessary precautions - half of the 
evacuees returned home. Overall, 1,473,391 people were evacuated in this first wave. ${ }^{1}$ The evacuations were organized by school, and in the end one third of applicable children were shipped to reception areas. In 1940, there was much more drama and urgency in the evacuation process as the German forces began to bomb major British cities. Around 1,250,000 people would be evacuated during the second stage of the war in a constant trickle of evacuees from different places at different times - unlike the flood of the first stage. ${ }^{2}$ The final part of the evacuations took place after the $1944 \mathrm{~V} 1$ and V2 rocket attacks on London. This was both the shortest and smallest evacuation, with only 307,600 organized evacuations and 552,000 privately arranged evacuations over the course of two months. ${ }^{3}$

Media of the Day

Although usually not academic in their scope, something must be said of the documentaries and media outputs as producers of memory. Movies like the aforementioned Chronicles of Narnia: The Lion, the Witch and the Wardrobe could be the only source for many people on how they will remember the evacuations should the traditional format of academic books or articles not be appealing or accessible to them. People can see and hear a representation of history, creating a much more memorable experience of the past. Current media will play a powerful role in defining memory by how they choose to represent it. People who are not necessarily dedicated to the study of history will remember and have a more emotional connection to the drama of the Pevensie children saying goodbye to their mother after nearly dying in an air raid more so than they would from reading about the organizational feats of local

\footnotetext{
${ }^{1}$ Carlton Jackson, Who Will Take Our Children? (Jefferson, NC: McFarland \& Company, Inc., Publishers, 2008), 26.

${ }^{2}$ John Welshman, Churchill's Children: The Evacuee Experience in Wartime Britain (New York, NY: Oxford University Press, 2010), 6.

${ }^{3}$ Ibid.
} 
councils in preparation for the evacuations. Yet media can also misrepresent history and create false memories of things that never happened, which is why the voice of the evacuees themselves is so important. But what about the media of the day? How does the 1939-1945 media represent the good and bad of evacuation and thus form a unique memory of the evacuations? Is media of the past anymore reliable than media today?

"The illiteracy of the future will be the ignorance of photography,"- 1927 photographer Laszlo Moholy-Nagy had a point; historians can often forget that photographs are much more important than an illustration in a book; they can be primary sources that historians can critically analyse. ${ }^{4}$ The same goes for historical films. As an artifact, they can provide both a window to what they were recording, making the media of the day key sources in examining the evacuations. Media sources include photographs, posters, newsreels, radio programs, and much more, each with their own unique contributions and influences on the study of the evacuations.

Although the types of media vary greatly, overall, they paint the evacuation process and outcome in a positive light. First, propaganda posters were used by a variety of government institutions to pass messages on to the general population as they trained them to think and have certain opinions. The British government produced several posters advocating for the evacuation program. Topics ranged from being willing to accept evacuees into their household, to warning mothers of the dangers of bringing their children back to the cities after they were evacuated. Propaganda posters were designed to be eye catching and to quickly impress upon the viewer an idea or feeling, and reveal a lot about the problems and concerns of the day. One example is a poster that says, "Leave this to us sonny - you ought to be out of London."

\footnotetext{
${ }^{4}$ Ibid., 257.

${ }^{5}$ Ministry of Health, Leave this to us Sonny, Art and Popular Design - Posters, Imperial War Museums, London England. Accessed November 4, 2016, http://www.iwm.org.uk/collections/item/object/5694.
} 
pretending to be an Auxiliary Fire Service (AFS) firefighter amidst the ruins of a bombed house addressed by a real AFS firefighter. The purpose of this message is to suggest to children and parents that it was expected for children to be counted among the evacuees, and that it was dangerous and against the wishes of those volunteering to protect London for them to remain behind. The poster presents evacuation as the better option, as opposed to children staying within the targeted cities, depicting the evacuations as a positive alternative to the danger and uselessness of a child staying in London. A similar idea is captured in the poster that says, "MOTHERS let them go - give them a chance of greater safety and health." 6 The poster depicts two nervous siblings, with the older brother gazing urgently at the viewer. The message is less implied than directly stated: mothers who kept their children at home prevented them from having access to relative safety and well-being in the countryside. Evacuation was presented as a good thing because it served to protect the children from the air raids of 1940-1941; if a mother were to keep her children at her side, she would be jeopardizing their lives. The need for these posters reveals that the government had difficulties in convincing parents of the benefits of the evacuation plan - the posters would not have been needed if all children had left the evacuation areas. Although the evacuation was not ideal for the parents of the time, as it forced them to part from their children and entrust them to strangers, the government presented one-sided propaganda about how evacuation was the best way to keep children safe and created a formal, government-approved memory of the benefits of the evacuation program.

Government television and radio programs strived to give a similar impression of the overwhelming benefits of the children's evacuations. A short newsreel from 1940 showed smiling children complacently climbing onto trains while a narrator explains,

\footnotetext{
${ }^{6}$ Ministry of Health, MOTHERS Let Them Go, 1939, Art and Popular Design - Posters, Imperial War Museums, London UK, Accessed November 4, 2016, http://www.iwm.org.uk/collections/item/object/31811.
} 
For the second time in this war and for another hundred and twenty thousand of them comes the great adventure. So it's goodbye to the cities and danger areas... and then not worrying, they're off on a holiday. These mass movements of our children are the greatest tribute in the world to the British way of life... we cannot forget the safety of our children on whom the future of our race depends. ${ }^{7}$

This newsreel presents the evacuations as an act of humanity, that they will care for their children unlike the enemies they are fighting against, and implying that not participating in the evacuations was an act of inhumanity against the children who stayed behind.

The children who were taken to the countryside would get to have adventures and a loving and safe house. This positive attitude is reinforced by the radio programs of the time. One program from September 1, 1939 kept listeners informed. "The evacuation of British children is going on smoothly and efficiently... The railways, the road transport organisations, the local authorities and teachers, the voluntary workers and, not least, the householders in the reception areas, are all playing their part splendidly." ${ }^{8}$ There was no mention of homesickness, the frustration of those on the receiving end, or other difficulties. Perhaps this was to keep the parents calm and reassured. Overall though, the first evacuation went well, so although negative points are excluded and children's experiences are generalized, the radio was still telling the general truth.

Lastly, photographs taken during the evacuations largely present a positive experience, but in more candid shots they can reveal that it was not a perfect exodus from the dangerous areas. One of the popular subjects of photographers during the evacuations were smiling children as they set off for the countryside. One such photograph depicts a crowd of children, all well

\footnotetext{
${ }^{7}$ British Pathé, Evacuating the Children 1940, Film, 1047.30, June 17, 1940, http://www.britishpathe.com/video/evacuating-the-children.

${ }^{8}$ BBC, Children Evacuated on 1 September 1939, September 1939, http://www.bbc.co.uk/learning/schoolradio/subjects/history/ww2clips/eyewitness/evacuees_children.
} 
dressed, with smiles on nearly every face, standing in the Brent train station in $1940 .{ }^{9}$ This would lead the viewer to believe the evacuations were a source of joy and excitement for the children. It seems an organized and positive affair, like a prolonged field trip. Photographs such as this establish the process of evacuating as successful, judging by the crowds of relatively happy children. Away from the bombs, the children could live lives free from fear. However, photographs can also reveal more about the raw, candid sadness that inevitably accompanied evacuation for many children. There is a picture of a young girl standing alone on a train platform, sobbing as she looks at the camera. ${ }^{10}$ She seems either terrified of where she is going, or is already homesick for the parents that she left behind. This picture and others like it are important because they are media of the day, but they are not completely biased in trying to make the evacuations seem next to perfect.

There were challenges that the British people had to overcome. However, these photographs may not have been as wide spread or as exposed publication during the war, and therefore there may have been less concern over reassuring parents with constant positive portrayals of the evacuations. Nevertheless, pictures reveal very different and important information that written documents or memory would not be able to provide.

Historians face advantages and disadvantages when using the media of the past to analyse an element of history. Newsreels, photographs, and the like help capture a moment of everyday life. From it, a historian can learn of clothes, attitudes, location, and other elements that would not necessarily be recorded by hand. Pictures and video can be taken nearly anywhere and were not bound to the literate or the wealthy. Therefore, pictures play an especially important role in

\footnotetext{
${ }^{9}$ Laura Clouting, "The Evacuated Children of the Second World War, Imperial War Museums, Accessed November 4, 2016, http://www.iwm.org.uk/history/the-evacuated-children-of-the-second-world-war.

${ }^{10}$ Mike Brown, Evacuees of the Second World War (Oxford, UK: Shire Publications, 2009), 28.
} 
social history and the study of everyday people. Media can be staged, so historians should be conscious of this as they examine things like photographs. There can be indications that would lead a person to doubt its authenticity, but even the most natural of photograph could still be a fake. Photographs are also not always accompanied with a description. Historians cannot know for sure where or when a poster specifically hung, nor where or when a photograph was taken when there is no accompanying explanation. This requires additional analysis of this type of source, as well as questions posed for every source, such as what the author or artist wanted to show, and if the source could be charged with any bias.

Overall, posters, videos, and photographs play an important part in forming a unified memory of the children's evacuation experiences. They are easier sources for viewers to absorb because they require less effort than reading - historians and the general population alike need only look or watch to comprehend the source. It can also use other senses, such as hearing, to involve the viewer more fully. Visual media makes history more real because people can see what happened and who was involved right in front of them. This will inevitably leave a greater impact, and will play a bigger role in historical memory, despite it not being the most academic or trustworthy of sources. Historians cannot just use them as illustrations, they must be analysed and addressed because they are what visual learners will remember about the evacuation experiences.

\section{$\underline{\text { Memoirs }}$}

The children themselves are important sources for understanding the evacuations. Realising this, many former evacuees, now senior citizens, have left behind memoirs of their wartime evacuation experiences. Overall, they have a very narrow approach to understanding the evacuations; they look at their lives and the lives of their immediate relations, and largely ignore 
the comparatively broad views of secondary sources in their recounts of history. Ergo, the former evacuees either remember their wartime experiences in a positive light, or a very negative one. These memoirs are important because they present the evacuation as judged by individuals. To one person, it may have been a disaster, despite what the statistics and historians have presented. Not all former evacuees see their past in such black and white terms, so it is interesting to see what an individual deems good, bad, or important in their memoirs.

The BBC's Archive for 'Memories of the Second World War' is filled with evacuation stories, and many of the submitted works are overwhelmingly positive, each in their own way. The most common and powerful memory that former evacuees who had a good experience in the countryside have are of their loving foster parents. This can be seen in the story of a boy named John, a young evacuee in 1940. After he arrived in Cornwall, it was not long before he had "settled down quite happily. Aunty and Uncle as [he] called them being childless soon made [him] one of the family." ${ }^{11}$ A boy named Terence had similar positive experiences after living with his host family since 1939. At one point, when Terence was shopping in a larger city close by, it came under attack by an air raid. Terence and his brother nearly gave their Auntie Rosie a heart attack for running towards the danger, and it was only her hug that could calm them. When it came time for him and his brother to leave at the end of the war, Uncle Jack and Auntie Rosie mourned their departure. ${ }^{12}$

This shows the deep emotional attachment that many foster parents developed for the evacuees that could sometimes override the attachment the children had to their biological

\footnotetext{
11 John Pavis, "Evacuation 1940: Life as a Farm Boy in Cornwall - Chapel, Oil Lamps and Signs of War," WW2 People's War: An Archive of World War Two Memories - Written by the Public, Gathered by the BBC, Johnpavis: November 8, 2003. http://www.bbc.co.uk/history/ww2peopleswar/stories/19/a1992819.shtml.

12 Terence Frisby, “A code of kisses that spelt, 'We miss you, Mum': The story of two frightened evacuees taken to the country to escape Hitler's bombs," The Daily Mail, September 4, 2009. http://www.dailymail.co.uk/news/article1211281/The-story-frightened-evacuees-taken-country-escape-Hitlers-bombs.html.
} 
parents. Intentionally or not, the evacuations inspired new relationships between city and country folk throughout the war years. It encouraged the pursuit of love and parenthood for those who could not have children while making sure that John, Terence, and the other children who had loving foster parents felt safe and provided for.

Not only did many of the children have loving foster parents, but they also could be children in their new environment of the countryside. A 1940 evacuee named Patrick could play, learn, and grow without the fear of nightly air raids or sea invasions. He could play games, build relationships, and grow into a teenager. He developed in a safe environment. Patrick went to the pictures on weekends, played marbles with his classmates, and went on a family holiday with his host parents. ${ }^{13}$ At the time, the British displayed a belief that the children had to be saved. In many ways, simply allowing the children to grow up away from the pressures of war was a way to fulfill this desire. War could take away a life or livelihood in a moment, and it could leave lasting mental and social impacts on those who experience it. For the children, being able to have what could be considered a nearly normal life helped them to be healthy and hopeful.

There are many other small ways that the memoirs of the evacuees reveal the benefits of evacuation, from experiencing new cultures and peoples, to the simple excitement of the journey. The important part of these memoirs is that they are raw and real in revealing how an individual child experienced the war - they do not shy away from situations where children faced the many negative consequences of war in their personal lives. First, in opposition to the loving families that John and Terence grew close to, some children faced abusive host families. Audrey and her sister were among the children who left for the countryside, and had several run-ins with poor

\footnotetext{
${ }^{13}$ Patrick Devine, "Patrick's Evacuation Story," WW2 People's War: An Archive of World War Two Memories Written by the Public, Gathered by the BBC, June 7, 2004. http://www.bbc.co.uk/history/ww2peopleswar/stories/38/a2714438.shtml.
} 
parenting. For example, Audrey was beaten by her second host mother whenever she would wet the bed, among other occasions. Audrey recounts one particularly harsh event in that household:

We went to bed every night and prayed to God not to let us wet the bed. One particular morning we awoke to find the bed drenched as usual, and Mrs Taylor was even more angry than usual. It was a shear icicle day and she shoved me first into the back yard naked, and threw a pail of freezing water over me, then proceeded to break the ice in the water butt to throw at me. It was like shards of glass hitting my body and of course drew blood..$^{14}$

Today, Audrey believes "the six years of evacuation were ones of waiting and longing.

[She is] sure [she] gained many things from [her] years in Bletchington, but the overall feeling is one of loss," and that, "the media nowadays portray evacuees as having a wonderful time, but [she thinks] these were in the minority." 15 Audrey decided that she would not let this negative experience get the better of her, but as she stated, she was not the only one to face unhappiness.

Evacuees often had a hard time fitting in with the local children in their neighbourhood and at school. They could be ostracized for their accents or appearance. Adults would look down on the London Eastenders as well. Terence, who was welcomed by his foster parents, had a harder time adjusting to the local children: "Us vackies and the local children looked at each other and it was instant war. They only had to open their mouths to be objects of ridicule to us.

'Whirr be you fram, then?' was greeted with suppressed giggles and: 'You talk funny.'

'No, us don't. You do.' 'Townies. Slum kids.' 'Turnips. Yokels. Clodhoppers."'16

The evacuees were already stressed from being away from their homes and families, so being excluded from the local community of classmates must have made them feel like they did

\footnotetext{
${ }^{14}$ Audrey Demers, "Memories of the Lost Years in Oxfordshire (1939-1945), WW2 People's War: An Archive of World War Two Memories - Written by the Public, Gathered by the BBC, November 9, 2004. http://www.bbc.co.uk/history/ww2peopleswar/stories/07/a2007307.shtml.

${ }^{15}$ Ibid.

${ }^{16}$ Frisby, "A code of kisses that spelt, 'We miss you, Mum."”
} 
not belong in London or in the countryside. This also shows that there was an attitude of "urban versus rural" in Britain at the time. Children learn their behaviour from the adults around them. Bringing many Londoners into an area that looked down on "slum kids" and other city-dwellers was bound to create conflict and uneasiness. The hardships of trying to fit in were further accentuated by differences in religion that some children had to face in their foster homes. One former evacuee named Sonya had to balance Jewish diet restrictions and a negligent foster mother. Sonya recounts, "We had to eat the food put in front of us and this proved a problem. As we were Jewish, we knew we should not eat pork - and in fact, I could not eat it." ${ }^{17}$ The foster mother of a Jewish boy named Martin tried to enroll him and his brother in Sunday school until his parents arrived and "they were able to explain the difference between a Jew and a Christian."18 These communities were Christian, so meeting someone other than that faith would have been a new and confusing experience. The Jewish evacuees had a hard time fitting in to the religious landscape of their new communities, and similar experiences happened for even different church denominations and other religions.

The former evacuees remember struggling to return back home after the war. John and Terence had good experiences with their foster parents, making the farewells even harder and more emotional. The issue goes further than that; children returned to broken homes and unfamiliar adults who they once lived with. Former evacuee Val remembers that she "returned to a very unhappy home where [her] Father would get drunk and knock [her] Mother about, often

\footnotetext{
${ }^{17}$ Sonya Brett, "Evacuated: Clapton to Cornwall," WW2 People's War: An Archive of World War Two Memories Written by the Public, Gathered by the BBC, December 27, 2003. http://www.bbc.co.uk/history/ww2peopleswar/stories/00/a2157400.shtml.

${ }^{18}$ Martin Vandervelde, "Memories of an Evacuee 1939," WW2 People's War: An Archive of World War Two Memories - Written by the Public, Gathered by the BBC, June 8, 2004. http://www.bbc.co.uk/history/ww2peopleswar/stories/24/a2722024.shtml.
} 
resulting in her ending up in hospital." ${ }^{19}$ It was simply expected that a child would return home, despite how bad their former home life was. It also tore apart all the relationships that the children had made in the years in the countryside. Despite their distance from the cities, the evacuees were not excluded from the fragmentation of normal life because of the war.

The memoirs encourage the formation of a "grey" historical memory of the evacuations they were neither all good nor all bad, and must be judged on an individual basis. To one person, it may have been a wonderful time, but for others, they were the worst years of their lives and had to be overcome to progress in their lives. Memoirs are personal. They provide an individual approach to history. They show what everyday experiences were like for an individual. These memoirs are interesting in and of themselves for showing what kinds of things former evacuees thought important and worth remembering. They do not remember the news of the war, or where they were when a major battle took place. They remember taking a trip with their host family, playing games with their classmates, or talking with Canadian soldiers. A generalized, sweeping view of an historical event ignores the wide variety of individual experiences historians can find amongst memoirs. They provide a unique perspective into history that other sources cannot.

Memoirs can also have a unique kind of bias. In general, "They recount only what people found worthy of note about their own age - which may not be what interests us today."20 Historians must dig through a lot of general information to find the gems that relate to their research topic. It can be tedious, but at the same time, they can help historians understand what was important during that time. However, memoirs can also distort history. ${ }^{21}$ Authors are subject

\footnotetext{
${ }^{19}$ Val Shoulder, "Childhood Days in Wartime Years," WW2 People's War: An Archive of World War Two Memories - Written by the Public, Gathered by the BBC, November 9, 2003. http://www.bbc.co.uk/history/ww2peopleswar/stories/87/a2002087.shtml.

20 Tosh, The Pursuit of History, 93.

${ }^{21}$ Ibid., 95.
} 
to faulty memory, misinterpretation of what they experienced, or the influence of later cultural beliefs and norms on their memory. Historians must take whatever they learn and compare it to other types of sources to get a fuller view of history from that time. Like oral history, there are also questions of the validity and reliability of memoirs. How reliable is the information provided, and how is it shaped by the current time and culture $?^{22}$ Especially given the large gap in time between childhood experiences as evacuees and the early $21^{\text {st }}$ Century, how long have memories held up to the test of time? How do historians know that these are not just false memories or memories fabricated by what they have read and seen about the evacuations since experiencing it? These are questions historians in particular must consider if they are to use them in their academic work.

\section{$\underline{\text { Secondary Sources }}$}

Perhaps the most influential type of source for examining the evacuations throughout Second World War Britain found within the field of history are secondary sources - books, articles, and reports written by historians. They provide a unique perspective on the debate concerning the good and bad aspects of the evacuations by including an analysis on the structure and organization of the events - something that the everyday child involved would be completely naïve to at the time. From an organizational standpoint, secondary sources tend to praise the success of such evacuations despite the ensuing chaos. Historians also do not shy away from recognizing that there were shortcomings in the evacuations, but their secondary sources generally look at these advantages and shortcomings on a broad scale, with occasional inclusions of specific examples to prove their point. Secondary sources show that despite the shortcomings

\footnotetext{
22 Trevor Lummis, "Structure and Validity in Oral Evidence," The Oral History Reader, ed. Robert Perks and Alistair Thomson (New York, NY: Routledge, 2002), 273.
} 
and hardships of the British evacuation plans of the Second World War, the evacuations were a force of good in the overall scheme of things.

Evacuees were far more safe from the bombs and rockets than they were while at home. This is the largest and most obvious reason secondary sources give for how the evacuations were a success in Britain. While it is not blatantly pointed out, many secondary sources heavily imply that the evacuations were overwhelmingly positive. For example, in Wartime Childhood, a book that covers what life was like for the children still left in the major cities, a brief description follows a posed shot of a first aid post: "Over 15,000 children under the age of 16 were killed, missing, or seriously wounded during the Blitz." ${ }^{23}$ During the 1940-1941 Blitz, there were severe safety hazards for the children in highly populated areas because the Germans targeted cities, industrial areas, and military bases during the air raids. Anyone left in the targeted zones was a pending casualty, regardless of demographic age. The numbers for youth casualties could have been a lot higher if not for the evacuation plan. In secondary sources, this issue is portrayed as one of rationality while looking at the big picture of the British wartime experience. Keeping the children away from the bombs was worth any individual displeasure felt by the children or parents. Secondary sources also look at the benefits the evacuations had on quality of life and British society. The most prevalent example of this was that forcing impoverished children out of their environment brought attention to just how low the quality of life was for London Eastenders. The British government had no idea just how bad it was for the working-class and brought postwar reforms on housing and nutrition to fruition. ${ }^{24}$ An extreme event like wartime evacuations showed the disenfranchisement of many Londoners. The evacuations brought about

\footnotetext{
${ }^{23}$ Mike Brown, Wartime Childhood (New York, NY: Shire Publications, 2009), 25.

${ }^{24}$ Carlton Jackson, Who Will Take our Children? The British Evacuation Program of World War II (Jefferson, NC: McFarland \& Company Inc., Publishers, 2008), 32.
} 
the unexpected success of government assistance for the poor. Historians are able to argue this because they can examine sources beyond the immediate dates of the historical event and can see the effects of specific decisions and outcomes in the long-run. As well, historians seem overwhelmingly impressed when they consider what challenges the evacuees and organizers had to face because things went quite well overall. In other words, given what the program had to work with, it was met with surprising success. In the first wave of evacuations, train stations were chaotic, with arrival and departure times unreliable, commuters and soldiers in the way, and scared or excited children outnumbering their guardians. Sometimes school groups would go to the wrong destination, and sometimes crying mothers would grab their children and take them home before they could leave. On arrival, local villagers struggled to accept what they saw as a disruption to the daily life and culture of their communities. ${ }^{25}$ Secondary sources recognise that there were little things that added up to make notable challenges during the evacuations. But despite all this, there was overall no "single accident or casualty" out of all the children in the first wave of the evacuations. ${ }^{26}$ In the secondary sources, this ability to rise above the difficulty and overcome the trials before them was what made it so successful in the eyes of historians.

There are positive and negative aspects to using secondary sources. From essay writing in high school to undergraduate research, secondary sources are the most easily accessible, with libraries and online databases not far out of reach. Although archives are starting to digitalize primary sources, often a researcher is not so fortunate, and must travel to the archives to see a primary source in person. If the researcher's home university does not carry or have access to a secondary source, it can often be ordered in via interlibrary loans. One of a kind primary sources have far less chance of going through shipping; they are simply too valuable. It should be noted,

\footnotetext{
${ }^{25}$ Ibid., 41.

${ }^{26}$ Ibid., 26.
} 
however, that certain secondary sources are easier to find than others - newer books are readily available online and at younger universities, while books published in the 1950s and 1960s on the British evacuations are out of print and not as easily accessible. Secondary sources can provide analysis for primary sources, thus helping guide their readers towards conclusions about the subject matter, and providing insight into historical events and challenging pre-conceived ideas. Students and researchers alike can learn new ways of thinking by examining the historians' arguments. Although it could be considered an easy way out, it can be helpful to researchers to have someone else detail their opinion on an event or primary source to guide thinking and provide some context for primary source analysis.

Furthermore, secondary sources can help serve as further validation for hypotheses: when two people come to the same conclusion (the historian who wrote the secondary source and the researcher), it can encourage the researcher that they are on the right track. In the social sciences, tests need to be able to be replicated for them to gain further validity as a proven hypothesis, and the same can be said for historical analysis. The opposite, however, can be a positive of secondary sources as well. Researchers must be able to challenge the status quo of existing historical research and narratives. Secondary sources are necessary in research to ensure that the same ideas are not replicated repeatedly instead of historians presenting new ways to think about history. Secondary sources can broaden the readers' and researchers' perspective, while inviting the exploration of a topic that already exists. Historians of secondary sources can pull from multiple fields of study to round out their approach to a given historical topic, such as academic works in sociology, psychology, law, medicine, aboriginal studies, and so on. Previous academic works are important sources in understanding the past. 
That being said, researchers must be cautious in their use of secondary sources in their studies. One school of thought does not believe historians should write history at all and instead use primary sources as the only source of education for the past. As distinguished Oxford Regius Professor, V.H. Galbraith put it: "What really matters in the long run is not so much what we write about history now, or what others have written, as the original sources themselves... The power of unlimited inspiration to successive generations lies in the original sources." ${ }^{27}$ While this way of thinking is unrealistic if historians ever hope to make sense of past events and their relevancy, it brings up the important idea that primary sources are not used nearly enough in comparison to secondary sources. For example, using secondary sources can devalue the voices of the evacuees themselves in how the history of the evacuations is remembered. Researchers must also understand just how complex history is. Using only a few secondary sources without primary sources will only provide a very narrow and biased view of the historical event or period and may leave unconventional topics undiscussed. Researchers must come to their own conclusions on primary sources and not just trust historians' views. They must also look at what kinds of sources historians have used in their papers. In the 1989 book The Children's War: Evacuation 1939-1945, Ruth Inglis lists largely secondary sources, such as novels and articles, with some primary sources in the form of government publications and surveys. ${ }^{28}$ Throughout her book, there are many quotes from evacuees. Looking back at the sources she used, the list includes many memoirs and compilations written years after the Second World War. Although these books are invaluable, the fact that they are officially published documents could imply editor interference. It also shows that Inglis did not prioritise using photographs, videos, and

\footnotetext{
27 John Tosh, The Pursuit of History $5^{\text {th }}$ ed. (Harlow, UK: Pearson Education Limited, 2010), 148.

${ }^{28}$ Ruth Inglis, The Children's War: Evacuation 1939-1945 (London, UK: William Collins Sons \& Co. Ltd., 1989), $169-171$.
} 
posters as sources, indicating the historians' disbelief in the importance of these sources. So even in the 1980s, although primary and secondary sources are used, they are underrepresented in comparison to secondary sources. This is just one approach historians have taken when dealing with sources.

In Niko Gärtner's Operation Pied Piper: The Wartime Evacuation of Schoolchildren from London and Berlin 1938-1946, published in 2012, the author seems to place more importance on primary sources by pointing out the most important documents of each chapter, and then including other primary sources and contemporary media sourced. ${ }^{29}$ The historian clearly labels the sources, perhaps to stress his use of primary sources. However, they are largely studies and newspaper articles from the time, and like Inglis, Gärtner does not include interviews, diaries, or direct primary sources. Furthermore, following two and a half pages on additional primary and contemporary sources, Gärtner's list of secondary literature sources is nearly nine pages, dwarfing his use of primary sources. This shows that historians are still critical of primary sources, and perhaps shows the stress historians face with exploring the historiography of their topic in academia to produce a well-received book by their peers. There is some difference in the sources used between the 1980s and the 2010s, but they are largely quite similar, with newer books perhaps including even more secondary sources. Researchers must look at the primary sources themselves and not just through the lens of secondary sources.

Historians can be biased, and this will impact their writing. Some historians take a narrative approach to history, while others focus on quantitative evidence. A researcher must make sure to not take a one-sided opinion as a complete view of the past, lest they pass on these biases to their readers as factual, or face challenges from historians who have used primary

\footnotetext{
${ }^{29}$ Niko Gärtner, Operation Pied Piper: The Wartime Evacuation of Schoolchildren from London and Berlin 19381946 (Charlotte, NC: Information Age Publishing, 2012), 183-188.
} 
sources and have noted discrepancies within the research. Researchers must consider the historian's credentials, and must be able to separate academic research from popular history written by journalists and other writers outside the realm of professional historical study. Historians can be shaped by the historiography of the time in which they are writing as well. For example, in the 1960s, the "tradition of social history was revived and expanded" in the movement that focused on "history from below." ${ }^{30}$ This inspired historians to look at the everyday people experiences, and this can be seen in some quantity in the books on the British evacuees published in the 1960s and later - some books entirely focus on memoirs, such as Robert Westall's Children of the Blitz: Memories of Wartime Children from 1985, while other books such as Carlton Jackson's Who Will Take Our Children?: The British Evacuation Program of World War II punctuates their broad topic with quotes and stories from middle to lower class British children to cut through the political and top-down analysis of history. ${ }^{31}$ In summary, secondary sources are important pieces that make up a well-rounded body of research, but one must be careful to not rely to heavily on them because they can contain faulty or onesided history.

Secondary sources have played a very important role in establishing historical memory of the Blitz. For those who casually seek out further information about the evacuations, secondary sources are most likely where they will turn. This could be because of easy access, or because one source will provide an overview of the evacuations instead of having to try and hunt down numerous primary sources that only cover a select part of the evacuation narrative. What the historian covers in their book will be what the reader will apply to their knowledge of the

\footnotetext{
${ }^{30}$ Tosh, The Pursuit of History, 71.

${ }^{31}$ Robert Westall ed., Children of the Blitz: Memories of Wartime Children (Middlesex, UK: Viking - Penguin Books Ltd., 1985); Jackson, Who Will Take Our Children?
} 
evacuations. In this way, what historians present as the past will be taken and adapted into the general memory of the event. That they are writing about it at all is a starting point for creating a memory of the evacuations, but if secondary sources give an overall view of what happened during the evacuations with a distinct lack of individuality within the stories it tells, then that will be how people view the evacuations. They will see an issue of numbers and movement, not one of personal struggle or discovery.

\section{Conclusion}

In conclusion, all three of the different source types in this essay - media, memoirs, and secondary sources - have strengths and weaknesses. They all present the history of British evacuations differently, from positive experiences to negative experiences, and everything in between. When historians combine the sources, they can give an interesting and multi-layered perspective of the British children's evacuation experiences during the Second World War. Modern movies and media may play a large role in bringing awareness to the evacuations as an historical event. Yet it is up to historians to take the lead in establishing healthy trends in how public and academic memory of the evacuations take shape so future generations can better understand the past. 


\section{Bibliography}

BBC. Children Evacuated on 1 September 1939. September 1939.

http://www.bbc.co.uk/learning/schoolradio/subjects/history/ww2clips/eyewitness/evacue es_children.

---. "We Have Been Evacuated." Evacuees from Manchester Interviewed. September 1939.

http://www.bbc.co.uk/learning/schoolradio/subjects/history/ww2clips/eyewitness/evacue es.

Brett, Sonya. "Evacuated: Clapton to Cornwall." WW2 People's War: An Archive of World War Two Memories - Written by the Public, Gathered by the BBC. December 27, 2003. http://www.bbc.co.uk/history/ww2peopleswar/stories/00/a2157400.shtml.

British Pathé. Evacuating the Children 1940. Film, 1047.30. June 17, 1940. http://www.britishpathe.com/video/evacuating-the-children.

Brown, Mike. Evacuees of the Second World War. Oxford, UK: Shire Publications, 2009. Print.

---. Wartime Childhood. Oxford, UK: Shire Publications, 2009. Print.

Clouting, Laura. "The Evacuated Children of the Second World War. Imperial War Museums. Accessed November 4, 2016. http://www.iwm.org.uk/history/the-evacuated-children-ofthe-second-world-war.

Demers, Audrey. "Memories of the Lost Years in Oxfordshire (1939-1945)." WW2 People's War: An Archive of World War Two Memories - Written by the Public, Gathered by the $B B C$. November 9, 2003. http://www.bbc.co.uk/history/ww2peopleswar/stories/07/a2007307.shtml.

Frisby, Terence. "A code of kisses that spelt, 'We miss you, Mum': The story of two frightened evacuees taken to the country to escape Hitler's bombs." The Daily Mail. September 4, 2009. http://www.dailymail.co.uk/news/article-1211281/The-story-frightened-evacueestaken-country-escape-Hitlers-bombs.html.

Gärtner, Niko. Operation Pied Piper: The Wartime Evacuation of Schoolchildren from London and Berlin 1938-1946. Charlotte, NC: Information Age Publishing, 2012. Print.

Inglis, Ruth. The Children's War: Evacuation 1939-1945. London, UK: William Collins Sons \& Co. Ltd., 1989. Print.

Jackson, Carlton. Who Will Take Our Children?: The British Evacuation Program of World War II. Jefferson, NC: McFarland \& Company, Inc., Publishers, 2008. Print.

Lummis, Trevor. "Structure and Validity in Oral Evidence." The Oral History Reader, ed. Robert Perks and Alistair Thomson. New York, NY: Routledge, 2002. Ministry of Health. Leave 
this to us Sonny. Art and Popular Design - Posters, Imperial War Museum, London, UK. Accessed November 4, 2016. http://www.iwm.org.uk/collections/item/object/5694.

Ministry of Health. MOTHERS Let Them Go. 1939. Art and Popular Design - Posters, Imperial War Museum, London UK. Accessed November 4, 2016. http://www.iwm.org.uk/collections/item/object/31811.

Pavis, John. "Evacuation 1940: Life as a Farm Boy in Cornwall - Chapel, Oil Lamps and Signs of War." WW2 People's War: An Archive of World War Two Memories - Written by the Public, Gathered by the BBC. Johnpavis: November 8, 2003. http://www.bbc.co.uk/history/ww2peopleswar/stories/19/a1992819.shtml.

Shoulder, Val. "Childhood Days in Wartime Years." WW2 People's War: An Archive of World War Two Memories - Written by the Public, Gathered by the BBC. November 9, 2003. http://www.bbc.co.uk/history/ww2peopleswar/stories/87/a2002087.shtml.

Vandervelde, Martin. "Memories of an Evacuee 1939." WW2 People's War: An Archive of World War Two Memories - Written by the Public, Gathered by the BBC June 8, 2004. http://www.bbc.co.uk/history/ww2peopleswar/stories/24/a2722024.shtml.

Welshman, John. Churchill's Children: The Evacuee Experience in Wartime Britain. Oxford, UK: Oxford University Press, 2010. Print.

Westall, Robert ed., Children of the Blitz: Memories of Wartime Children. Middlesex, UK: Viking - Penguin Books Ltd., 1985. Print. 